\title{
短 報
}

水産練り製品中の脂質過酸化由来有毒 アルデヒド，4-ヒドロキシヘキセナール及び マロンアルデヒド含量の変動

境 正, ${ }^{1 *}$ 山口 徹, ${ }^{2}$ 河原 聡 ${ }^{1}$

( 2008 年 10 月 6 日受付, 2008 年 12 月 26 日受理)

1 宮崎大学農学部応用生物科学科, ${ }^{2}$ 山口商店

Changes in the contents of lipid oxidation-derived toxic aldehydes, 4-hydroxy-2-hexenal and malon aldehyde, in surimi products

TADASHI SAKAI, ${ }^{*}$ TOHRU YAMAGUCHI ${ }^{2}$ AND SATOSHI KAWAHARA ${ }^{1}$

${ }^{1}$ Department of Biochemistry and Applied Biosciences, Faculty of Agriculture, University of Miyazaki, Gakuenkibanadai-nishi, Miyazaki-shi, Miyazaki 889-2192, ${ }^{2}$ Yamaguchi Shouten, Tachibanadori-nishi, Miyazaki-shi, Miyazaki 880-0001, Japan

キーワード：4-ヒドロキシへキセナール，かまぼこ， ちくわ, マロンアルデヒド

魚肉及び畜肉の脂質過酸化による品質の低下は, 食品 化学及び食品衛生学上重大な問題である。1)この脂質過 酸化により多くの細胞毒性及び変異原性を持ったアルデ ヒドが生じる。その中でも，近年最も注目を集めている のが 4 位に $\mathrm{OH}$ 基を持つ $\alpha, \beta$ 不飽和アルデヒドである 4-ヒドロキシアルケナールである。魚肉に扔いては, その脂肪酸組成からエイコサペンタエン酸等の $\mathrm{n}-3$ 高 度不飽和脂肪酸より生じる4-ヒドロキシへキセナール (HHE) が重要である。HHE は強い細胞毒性2)及び変 異原性を持ち, 発ガンやアルツハイマ一型認知症等の疾 病との関連が疑われている。利したがって, 食品中の HHE 含量を調べることは水産食品学及び食品衛生学上 重要と考えられる。魚肉中の HHE に関する研究はいく つかある。2,4-7) 水産練り製品については多くの機能性が 報告されて抢り, 8-10) 水産食品のなかで最も重要な製品 の一つと考えられている。その水産練り製品中の HHE 含量について先に報告した結果は，製造方法や貯蔵期間 により大きく異なっている可能性を示していた。11) そこ で, 実際の練り製品製造現場において, 製品中の脂肪酸 含量が異なっている上に加熱方法がガスによる直火焼き と蒸し器による蒸しと異なっているちくわとかまぼこに ついて，それらの違いが HHEの生成にどのような影響 を及ぼすか，加熱前後及び $0^{\circ} \mathrm{C}$ 貯蔵によって HHE 含量
がどのように変動するかについて調べた。また, HHE は脂質酸化の過程で生じるので, 指標としてマロンアル デヒド（MA）含量を測定した。さらに HHE は n-3 高 度不飽和脂肪酸 (PUFA) から生じるので, 加熱前のす り身及び加熱後の製品につき, 脂質含量と n-3 PUFA 含量についても測定した。

ちくわ及びかまぼこに用いたスケトウダラすり身の組 成を Table 1 に示した。出来上がったすり身をちくわは ガスにより坐り 5 分, 焼き 5 分計 10 分間加熱し（内部 の温度は $80 \sim 100^{\circ} \mathrm{C}$, , かまぼこは $40^{\circ} \mathrm{C}, 40$ 分間坐り蒸 し後, $90^{\circ} \mathrm{C}$ で 40 分間蒸した。すり身は直ちに HHE, $\mathrm{MA}$, 水分及び脂質含量及び n-3 PUFA 組成を測定し

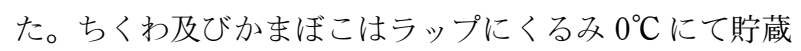
し, HHE 及びMA は貯蔵後 $0,1,2$ 日目に, 脂質含量 及びn-3 PUFA 組成は貯蔵 0 日目に測定した。HHE 含 量4)及びMA 含量は12) それぞれ Sakai らの HPLC 法に より行った。加熱後の両アルデヒド含量は水分含量の変 動を基に，すり身 $1 \mathrm{~g}$ あたりの值に換算した。脂質を Folch らの方法により抽出し, ${ }^{13)} \mathrm{n}-3$ PUFA 含量は Takenoyama らの方法により測定した。 ${ }^{14)} \mathrm{HHE}$ 及び MA 含量の結果は平均値士標準䛊差で示した。HHE 及 びMA含量の差の検定は Duncanの Multiple range tests ${ }^{15)}$ により行った。

原料であるすり身及び製品中の水分含量を Table 2 に, 脂質及び n-3 脂肪酸含量を Table 3 に, HHE 及び

Table 1 Composition of the surimi for chikuwa and kamaboko

\begin{tabular}{lcc}
\hline \multicolumn{1}{c}{ Ingredient (\%) } & Chikuwa & Kamaboko \\
\hline Fish meat (America, SA level) & 40.2 & 53.8 \\
Starch & 9.0 & 3.9 \\
Salt & 1.4 & 1.6 \\
Fish meat extract & 0 & 0.1 \\
Seasoning & 6.8 & 3.2 \\
Egg white & 4.1 & 4.8 \\
Water & 36.3 & 33.0 \\
\hline
\end{tabular}

Table 2 Water contents in chikuwa and kamaboko

\begin{tabular}{|c|c|c|c|c|}
\hline & \multicolumn{2}{|c|}{ Chikuwa } & \multicolumn{2}{|c|}{ Kamaboko } \\
\hline & Surimi & Product & Surimi & Product \\
\hline $\begin{array}{c}\text { Water contents } \\
(\%)\end{array}$ & $75.62 \pm 0.0$ & $68.01 \pm 1.37$ & $79.43 \pm 0.05$ & $79.04 \pm 0.09$ \\
\hline
\end{tabular}

Values (means $\pm \mathrm{SE}, \mathrm{n}=3$ )

* Tel : 81-985-58-7230. Fax : 81-985-58-2884. Email : sakaihhe@cc.miyazaki-u.ac.jp 
MA 含量の測定結果を Table 4 に示した。加熱後，ちく わの水分含量は $89.9 \%$ に減少し，かまぼこのそれはほ とんぞ減少しなかった。HHE 含量は有意ではないが増 加し, MA 含量は有意に増加した。この結果は, ガス による直火焼きという加熱処理及び原材料のすり身中に 脂質が多く含まれていることにより，脂質酸化が進行し たことを示唆している。他方, かまぼこでは加熱後, HHE 含量は変化せず MA 含量は有意に減少した。この 結果は, かまぼこは蒸すという直火焼きに比べマイルド な加熱処理及び原材料のすり身に脂質が少ないことによ り加工中に脂質酸化が殆ど進行しなかったことを示して いる。

ちくわにおいて HHE 含量は有意ではないが貯蔵 2 日 目に減少し, MA 含量は貯蔵 2 日目に有意に減少し た。両アルデヒドとも反応性に富んでいるので, 16$)$ 貯蔵 中に遊離またはタンパク質中のアミノ酸と反応して消失 した可能性が高いと思われる。他方，かまぼこでは HHE 含量は貯蔵期間中殆ど変化しなかったが, MA 含 量は貯蔵 2 日目に有意に増加し, かまぼこは $0^{\circ} \mathrm{C}$ 貯蔵 でも脂質酸化が進行することを示唆している。脂質酸化 は著しい品質の低下を引き起こす上に, 1) その生成産物 である HHE は強い細胞毒性2) や変異原性 ${ }^{17)}$ を持つ。ま た，弱いが経口毒性も持っているので, ${ }^{18)}$ 製造現場での

Table 3 Changes of total lipid and n-3 PUFA contents in chikuwa and kamaboko

\begin{tabular}{clcc}
\hline Sample & \multicolumn{1}{c}{ Fatty acids } & Surimi & Product \\
\hline Chikuwa & Total lipid $^{\mathrm{a}}$ & 2.54 & 3.05 \\
& $\alpha$-Linoleic acid $^{\mathrm{b}}$ & 62.8 & 63.8 \\
& Eicosapentaenoic acid $^{\mathrm{b}}$ & 13.7 & 14.7 \\
& Docosahexaenoic acid $^{\mathrm{b}}$ & 21.5 & 24.5 \\
\hline Kamaboko & Total lipid $^{\mathrm{a}}$ & 0.63 & 0.54 \\
& $\alpha^{- \text {Linoleic acid }^{\mathrm{b}}}$ & 2.0 & 5.0 \\
& Eicosapentaenoic acid $^{\mathrm{b}}$ & 52.7 & 54.8 \\
& Docosahexaenoic acid $^{\mathrm{b}}$ & 103.7 & 114.9 \\
\hline
\end{tabular}

a) $\mathrm{g} / 100 \mathrm{~g}$ wet weight

b) $\mathrm{mg} / \mathrm{g}$ lipid
脂質酸化進行抑制及び HHE 生成抑制に関する研究を行 う必要がある。

\section{文献}

1) Pearson AM, Gray JI, Wolzak AM, Horenstein NA. Safety implications of oxidized lipids in muscle food. Food Technol. 1983; 37: 121-129.

2) Sakai T, Sugamoto K, Eto N. Cytotoxicity of 4-hydroxy$2 E$-hexenal, a lipid peroxidation-derived aldehyde, and changes of its content in frozen yellowtail meat. J. Food Hyg. Soc. Japan 2000; 41: 368-370.

3) Esterbauer H, Schaur RJ, Zollner H. Chemistry and biochemistry of 4-hydroxynonenal, malonaldehyde and related aldehydes. Free Radical Biol. Med. 1991; 11: 81128.

4) Sakai T, Matsushita Y, Sugamoto K, Uchida K. Lipid peroxidation-derived hepatotoxic aldehyde, 4-hydroxy-2 -hexenal, in fish. Biosci. Biotechnol. Biochem. 1997; 61: 1399-1400.

5) Munasinghe DMS, Ichimaru K, Ryuno M, Ueki N, Matsui T, Sugamoto K, Kawahara S, Sakai T. Lipid peroxidation-derived hepatotoxic aldehydes, 4-hydroxy-2Ehexenal in smoked fish meat products. Fish. Sci. 2003; 69: 189-194.

6) Munasinghe DMS, Kawahara S, Sakai T. Effects of $\mathrm{NaCl}$ on 4-hydroxy-2-hexenal formation in yellowtail meat stored at $0^{\circ} \mathrm{C}$. Biosci. Biotechnol. Biochem. 2006; 70: 30363038.

7）境 正, 中村康宏. 水産練り製品中の脂質酸化由来了 ルデヒド, 4-ヒドロキシへキセナール含量. 日水誌 2008; 74: 213-215.

8) Nagai T, Suzuki N, Nagashima T. Antioxidative activities and angiotensin I-converting enzyme inhibitory activities of enzymatic hydrolysates from commercial kamaboko type samples. Food Sci. Technol. Inter. 2006; 12: 335-346.

9) Nagai T, Suzuki N, Tanoue Y, Kai N, Nagashima T. Physical properties of kamaboko derived from walleye pollack (Theragra chalcogramma) surimi and functional properties of its enzymatic hydrolysates. J. Food Agri. Environ. 2007; 5: 76-81.

10) Yoshie-Stark Y, Tsukamoto M, Futagawa K, Kubota M, Ogushi M. Bioactivities of surimi from southern blue whiting prepared by different ways. Food Chem. 2008; in press.

11）境 正, 中村康宏. 水産練り製品中の脂質酸化由来了 ルデヒド，4-ヒドロキシヘキセナール含量. 日水誌 2008; 74: 213-215.

12) Sakai T, Habiro A, Kawahara S. High-performance liquid

Table 4 Changes in the HHE and MA contents in chikuwa and kamaboko

\begin{tabular}{lllrrr}
\hline \multirow{2}{*}{ Sample } & \multirow{2}{*}{ Aldehyde } & Surimi & \multicolumn{3}{c}{ Storage period (day) } \\
\cline { 4 - 6 } Chikuwa & HHE $(\mathrm{nmol} / \mathrm{g})$ & $0.26 \pm 0.08^{\mathrm{a}}$ & $0.37 \pm 0.11^{\mathrm{a}}$ & $0.11 \pm 0.01^{\mathrm{a}}$ & $0.12 \pm 0.07^{\mathrm{a}}$ \\
& MA $(\mu \mathrm{mol} / \mathrm{g})$ & $0.40 \pm 0.00^{\mathrm{a}}$ & $10.46 \pm 0.22^{\mathrm{b}}$ & $10.71 \pm 0.04^{\mathrm{b}}$ & $3.05 \pm 0.10^{\mathrm{c}}$ \\
\hline \multirow{2}{*}{ Kamaboko } & HHE $(\mathrm{nmol} / \mathrm{g})$ & $0.15 \pm 0.06^{\mathrm{a}}$ & $0.16 \pm 0.03^{\mathrm{a}}$ & $0.17 \pm 0.03^{\mathrm{a}}$ & $0.22 \pm 0.05^{\mathrm{a}}$ \\
& MA $(\mu \mathrm{mol} / \mathrm{g})$ & $1.75 \pm 0.10^{\mathrm{ac}}$ & $1.46 \pm 0.00^{\mathrm{b}}$ & $1.54 \pm 0.10^{\mathrm{ab}}$ & $1.83 \pm 0.06^{\mathrm{c}}$ \\
\hline
\end{tabular}

Mean (HHE: $n=5$, MA: $n=3) \pm$ SE.

Values in the same row with no common superscripts are significantly different $(p<0.05)$. 
chromatographic analysis of 1,3-diethyl-2-thiobarbituric acid-malonaldehyde adduct in fish meat. J. Chromatogr. $B$ 1999; 726: 313-316.

13) Folch J, Lees M, Sloane SGH. A simple method for the isolation and purification of total lipids from animal tissues. J. Biol. Chem. 1957; 226: 497-509.

14) Takenoyama S, Kawahara S, Murata H, Yamauchi K. Investigation of some preparation procedures of fatty acid methyl esters for capillary gas-liquid chromatographic analysis of conjugated linoleic acid in meat. Animal Sci.J. 1999; 70: 336-342.

15) Duncan DB. Multiple range and multiple F tests. Biomet- rics 1955; 11: 1-42.

16) Esterbauer H, Lipid peroxidation products: formation, chemical properties, and biological activities. In: Packer L, Sleter TF (eds). Free Radicals in Liver Injury. IRL Press. Oxford. 1985: 29-47.

17) Esterbauer H. Cytotoxicity and genotoxicity of lipid-oxidation products. Am. J. Clin. Nutr. 1993; $\mathbf{5 7}$ (suppl): 779S $-786 \mathrm{~S}$.

18）境正. 魚肉は不飽和脂肪酸の酸化によりどのような ダメージを受けるのか？4-ヒドロキシー2-へキセナール が筋肉タンパク質中のリジンと結合. 化学と生物 2004; 40: $84-85$. 